
університет імені Лесі Українки ORCID ID 0000-0002-3278-1900

Дмитро Пріма

Східноєвропейський національний університет імені Лесі Українки ORCID ID 0000-0002-2102-9932 DOI 10.24139/2312-5993/2020.03-04/237-244

\title{
ПРОЄКТНА ДІЯЛЬНІСТЬ УЧИТЕЛЯ ПОЧАТКОВОЇ ШКОЛИ: ТЕОРЕТИЧНІ АСПЕКТИ
}

Метою статті є розкриття деяких аспектів проєктної діяльності вчителя початкової школи, сутнісних ознак методу проєктів, проєктної технології. у статті використано методи дослідження: теоретичні (аналіз довідкових видань, науковопедагогічної літератури); інтерпретаційно-аналітичний метод, узагальнення. у контексті пошуку нових засобів і методів формування творчої особистості, ії життєво важливих компетентностей актуалізовано проєктну діяльність як одну з найпродуктивніших складових освітнього прочесу, що створює умови для творчого саморозвитку й самореалізачії учнів. Проаналізовано різні підходи щодо дерініцій «проєкт», «навчальний проєкт», «метод проєктів», «проєктна технологія», сутнісні ознаки яких поглиблюють розуміння поняття «проєктна діяльність».

Ключові слова: учитель початкової школи, метод проєктів, навчальний проєкт, проєкт, проєктна діяльність, проєктна технологія, технологія навчання.

Постановка проблеми. В Україні триває процес модернізації і реформування освітньої системи в контексті входження до світового простору, пошуку нових засобів і методів формування творчої особистості, іiі життєво важливих компетентностей. При цьому однією 3 найпродуктивніших складових освітнього процесу, що створює умови для творчого саморозвитку та самореалізації учнів, формує всі необхідні життєві компетенції, визначені Радою Європи як основні в XXI столітті полікультурні, мовленнєві, інформаційні, політичні та соціальні, є проєктна діяльність - технологія становлення особистості, передусім молодшого школяра, як активного учасника проєктно-життєвого простору, покликаного сприяти саморозвитку творчої, компетентної, гармонійної людини. Ми виходимо з того, що компетентнісно спрямована освіта передбачає внесення суттєвих змін у змістову, проєктно-технологічну, виховну, управлінську архітектоніку української школи, коли в структурі навчання посилюється роль і значення освоєння способів діяльності, підвищення їхньої технологічності, створення умов для активної соціальної дії, проєктної, дослідницької діяльності (Єрмаков, 2006). 
Аналіз актуальних досліджень засвідчив, по-перше, наявність наукових розробок, де розкриваються теоретичні засади проєктної діяльності (В. Гузеєв, О. Коберник, О. Пєхота, С. Сисоєва та ін.), аналізується iї зміст і значення (А. Вдовиченко, В. Сидоренко, А. Терещук та ін.), теоретично обґрунтовується метод проєктів і проєктна технологія (В. Зверєва, В. Лазарєв, М. Поташник, Г. Селевко та ін.), висвітлюються проблеми організації проєктної діяльності в початковій школі (Т. Башинська, Л. Коваль, О. Онопрієнко, В.Тименко та ін.). По-друге, відсутність єдиного погляду науковців щодо проблеми проєктної діяльності вчителя початкової школи.

Метою статті $€$ розкриття деяких аспектів проєктної діяльності вчителя початкової школи, сутнісних ознак методу проєктів, проєктної технології.

Виклад основного матеріалу. Передусім відзначимо, що серед дефініцій, що формують уявлення про проєктну діяльність учителя початкової школи загалом, виокремлюємо такі поняття, як «проєкт», «навчальний проєкт», «метод проєктів», «проєктні технології». А відтак, розкриємо їх сутність. Так, за Новим тлумачним словником української мови, проєкт - це «1. Сукупність документів (розрахунків, креслень, макетів тощо), необхідних для зведення споруд, виготовлення машин, приладів тощо. 2. Попередній текст якого-небудь документа, що виноситься на обговорення, затвердження; начерк. 3. Задуманий план дій; задум, намір» (Новий тлумачний словник української мови, 2008, с. 6).

На думку А. Лебедєва, проєкт - «сукупність певних дій, документів для створення реального об'єкта, предмета, різного роду теоретичного продукту. Це завжди творча діяльність» (Лебедев, 2002).

За твердженням О. Онопрієнко, у педагогічній літературі поняття «проєкт» (від лат. projectus - кинутий уперед) визначається, по-перше, як результат перетворювальної діяльності; по-друге, як мета і результат проєктування (Онопрієнко, 2013, с. 10).

Як слушно відзначає Н. Тализіна, «проєкти виступають у ролі доповнень і трансформ; вони спрямовані на те, щоб змінити існуючий стан справ. За змістом проєктування є перетворенням вже існуючих об'єктів у нову форму». Конструктивною вважаємо думку вченої, відповідно до якої проєктування є рушійним механізмом справді розвиваючого утворення, позаяк «предметом проєктування і $€$ створення умов (засобів, механізмів) розвитку системи утворення загалом, переходу з одного стану в інший» (Талызина, 1988, с. 115-116).

Нам імпонує позиція О.Пєхоти, згідно з якою проєкт характеризується як практика особистісно орієнтованого навчання у процесі конкретної праці учня, на основі його вільного вибору, з урахуванням його інтересів. При цьому вчена зауважує, що у свідомості учня це виглядає так: «Все, що я пізнаю, я знаю, для чого це мені треба і де 
я можу ці знання застосувати». Для педагога ж - це прагнення знайти розумний баланс між академічними знаннями, уміннями та навичками (Освітні технології, 2003).

Цінними нам видаються наукові узагальнення Р. Михайлишин щодо виокремлення науковцями різних категорійних ознак поняття «проєкт», а саме: С. Кримський - систематична форма організації діяльності у взаємозв'язку з ії теоретичними і практичними аспектами; Л. Ващенко інноваційна форма організації освітнього середовища, в основі якої лежить комплексний характер діяльності тимчасового колективу в умовах активної взаємодії з навколишнім середовищем; А. Мойсеєв - форма побудови цілеспрямованої діяльності; О. Пометун - цільовий акт діяльності, в основу якого покладено інтереси людини (Михайлишин, 2016, с. 44-45).

Заслуговує на увагу думка $€$. Полат, що визначає проєкт як сукупність навчально-пізнавальних прийомів, за допомогою яких учні набувають знання та навички в процесі планування та самостійного виконання певних практичних завдань із обов'язковою презентацією результатів (Полат, 2002); як спосіб досягнення дидактичної мети через детальну розробку проблеми (технології), що повинна завершитися цілком реальним, відчутним практичним результатом, оформлення тим чи іншим чином (Полат, 2000, с. 3).

Отже, крізь призму викладеного цілком правомірно стверджувати, що домінантною ідеєю, що утворює змістове ядро поняття «проєкт», $\epsilon$ «прагматична спрямованість на результат, який досягається за умови вирішення тієї чи іншої практично або теоретично значущої проблеми (А. Хуторськой). А відтак, виникає необхідність внести уточнення стосовно трактування поняття «навчальний проєкт».

Звертаємо увагу на те, що різноплановістю підходів відзначається й дефініціювання категорії «навчальний проєкт». Так, В. Симоненко навчальний (творчий) проєкт характеризує як самостійно розроблені та виготовлені товари (послуги) від ідеї до ії втілення, що має суб'єктну або об'єктну новизну і виконується під контролем та консультуванням учителя (Симоненко, 1999). За А. Хуторським, навчальний проєкт - це форма організації занять, яка передбачає комплексний характер діяльності всіх його учасників з отриманням освітньої продукції за певний проміжок часу (Хуторской, 2001).

У контексті окресленої проблеми оригінальним (і певною мірою контекстним) нам видається авторське бачення російського науковця $€$. Полата і щодо трактування поняття «навчальний проєкт» як об'єднаної навчально-пізнавальної творчої діяльності учнів-партнерів, організованої на основі комп'ютерних телекомунікацій, які мають спільну проблему, мету, узгоджені методи, способи діяльності, спрямовані на досягнення загального результату сумісної діяльності (Полат, 2002). 
Попри те, що кожне з наведених визначень поняття «навчальний проєкт» має певний сенс, однак, погоджуючись із О. Онопрієнко, вважаємо, що для початкової школи прийнятним $€$ розуміння навчального проєкту як особливого виду навчально-пізнавальної діяльності учнів, спрямованої на вирішення проблеми, пов'язаної зі створенням освітнього продукту, який має суб'єктивну чи об'єктивну цінність, а метод проєктів слід розглядати як спосіб організації такої діяльності (Онопрієнко, 2013, с. 17).

Стосовно методу проєктів, то за визначенням С. Пілюгіної, - це особистісно-орієнтований метод навчання, заснований на самостійній діяльності учнів щодо розробки проблеми й оформлення їі практичного результату.

На наш погляд, суттєва особливість методу проєктів акумульована у визначенні І. Зимньої та Т. Сахарової: «Проєкт - самостійно планована й реалізована учнями робота, у якій мовленнєве спілкування вплетене в інтелектуально-емоційний контекст іншої діяльності» (Зимняя, 1991, с. 9).

Як слушно відзначає К. Мелашенко, метод проєктів - це педагогічна технологія, що передбачає певну сукупність навчально-пізнавальних прийомів, які дозволяють розв'язати ту чи іншу проблему в результаті самостійних дій учнів із обов'язковою презентацією цих результатів (Мелашенко, 2006, с. 13).

У контексті окресленої проблеми конструктивною вважаємо думку вчених щодо виокремлення характерних ознак методу проєктів, як-от:

- наявність певної значущої для учнів проблеми;

- вихідний момент - інтереси дітей;

- домінування принципу самостійності в діяльності учнів;

- використання різноманітних форм діяльності школярів: індивідуальна, парна, групова;

- зв'язок теорії з практикою;

- зв'язок із реальним життям;

- забезпечення максимальної пізнавальної активності учнів;

- розвиток творчих навичок школярів, критичного мислення, умінь самостійно шукати інформацію;

- використання різноманітних методів, засобів навчання;

- здійснення монопредметних, міжпредметних та надпредметних зв'язків ;

- інтегрування знань, умінь із різних галузей науки і мистецтва;

- із об'єктів навчання учні перетворюються на суб'єктів навчання;

- включає в себе елементи особистісно орієнтованого навчання, педагогіки співробітництва, діяльнісного підходу в навчанні (Метод проектів: особливості застосування в початковій школі, 2009).

Отже, як бачимо, метод проєктів ґрунтується на ідеї спрямованості навчально-пізнавальної діяльності школярів на результат, що отримується 
через вирішення певної теоретично-практично значущої для учня проблеми. При цьому зовнішній результат - візуальний: його можна побачити, осмислити, оцінити, застосувати на практиці. Внутрішній же результат досвід діяльності - стане надбанням учня лише завдяки поєднанню компетенції й цінності, знання та вміння, що особливо важливо в молодшому шкільному віці, коли закладаються і формуються підвалини ціннісних настанов, особистісних якостей і ставлень. Із таких позицій застосування методу проєктів у початковій школі має на меті стимулювати інтерес учнів до певних проблем і розв'язувати ці проблеми через діяльність.

Крізь призму окресленого цілком правомірно стверджувати про різноаспектність підходів науковців щодо трактування змісту поняття «метод проєктів», про відсутність єдиної й чіткої парадигми його використання, що розуміється контекстно як метод, технологія навчання, вид навчання та діяльність, а також констатувати наявність у наукових текстах поруч із традиційним уживанням терміну «метод проєктів» відносно нового поняття «проєктна технологія».

Сутність проєктної технології, за Т.Подобєдовою, полягає у функціонуванні цілісної системи дидактичних засобів (змісту, методів, прийомів тощо), що адаптує освітній процес до структурних і організаційних вимог навчального проєктування (Подобєдова, 2005) як специфічного індивідуально-творчого процесу, що вимагає від кожного учасника оригінальних рішень, і водночас, як процес колективної творчості.

Проєктна діяльність, за Енциклопедією освіти, характеризується як конструктивна і продуктивна діяльність особистості, спрямована на розв'язання життєво значущої проблеми, досягнення кінцевого результату в процесі цілевизначення, планування і здійснення проєкту. Вона належить до унікальних способів людської практики, пов'язаної із передбаченням майбутнього, створенням його ідеального образу, здійсненням та оцінкою наслідків реалізації задумів. Проєктування виступає як творча, інноваційна діяльність, оскільки завжди спрямована на створення об'єктивно і суб'єктивно нового продукту (Енциклопедія освіти, 2008, с. 717).

Зауважимо, для успішного впровадження проєктної діяльності необхідно, щоб педагог із учителя перетворився на помічника, порадника, який завжди поруч із учнем. Суттєво, що при цьому проєктна діяльність розширює учню поле нової для нього діяльності, сприяючи тим самим появі широкого кола інтересів, і потім, через них, здійснює вплив на формування його переконань та світогляду (Матяш, 2000, с. 148).

Таким чином, резюмуючи викладене i погоджуючись із Н. Дереклеєвою, вважаємо, що проєктна діяльність учителя, зокрема початкової школи, має значний педагогічний потенціал, який розкривається через: сприяння соціальному розвитку тих, хто навчається; розвиток управлінських умінь у суб'єктів навчального процесу (робота в 
групі, планування, розподіл обов'язків тощо); формування соціальних навичок кооперування, спільного прийняття рішень, розуміння й оцінювання того, як індивідуальні внески можуть скласти успішне ціле; серію продуктивної діяльності, де все спрямоване на досягнення кінцевого результату - продукту: ті, хто навчається, можуть реально відчути радість успіху; розвиток незалежності, тому що ті, хто навчаються, приймають власні рішення; сприяння розвитку тих, хто навчається, почуття впевненості у власних можливостях, адже передбачає презентацію та захист отриманих результатів; позитивний вплив на емоційний і персональний розвиток того, хто навчається (Дереклеева, 2001).

Висновки та перспективи подальших наукових розвідок. Отже, нами проаналізовано дефініції «проєкт», «навчальний проєкт», «метод проєктів», «проєктна технологія», сутнісні ознаки яких поглиблюють розуміння поняття «проєктна діяльність». Для вчителя початкової школи реалізація ціннісних настанов проєктної діяльності спричиняє зміни професійної позиції вчителя, коли з носія знань він перетворюється на організатора пізнавальної діяльності своїх учнів, забезпечує досягнення нової якості освітнього процесу, трансформуючи його у простір «вирощування нових компетенцій, які стимулюють самоорганізацію педагогічної системи як відкритої, спрямованої на становлення особистості як суб'єкта життєтворчості; існування проєктно-технологічного типу організаційної культури діяльності» (Енциклопедія освіти, 2008, с. 718). Відтак, перспективи подальших наукових розвідок пов'язуємо 3 розкриттям виховних можливостей проєктної діяльності сучасного вчителя початкової школи.

\section{ЛІТЕРАТУРА}

Єрмаков, І. (2006). Компетентнісний потенціал проектної діяльності. Школа (Шкільний cвim), 5, 5-11 (Yermakov, I. (2006). Competence potential of project activity. School (School world), 5, 5-11. Retrieved from: old.ippo.edu.te.ua/files/metod work/structure mw/09 kompetent potencial.pdf

Новий тлумачний словник української мови, Т. 3 (2008). Київ: Аконіт (New explanatory dictionary of the Ukrainian language, Vol. 3 (2008). Kyiv: Aconite).

Лебедева, А. И., Иванова, Е. В. (2002). Метод проектов в продуктивном обучении. Школьная технология, 5,116-120 (Lebedeva, A. I. \& Ivanova, E. V. (2002). Project method in productive learning. School technology, 5, 116-120).

Онопрієнко, О. В. (2013). Проектна діяльність у початковій школі: методичний посібник. К.: ТОВ «СІTIПPIHT» (Onoprienko, O. V. (2013). Project activity in primary school: manual. Kyiv: CITYPRINT LLC.).

Талызина, Н.Ф. (1988). Формирование познавательной деятельности младиих школьников. М.: Просвещение (Talyzina, N. F. (1988). Formation of cognitive activity of junior schoolchildren. M oscow: Enlightenment).

Пєхота, О. М., Кіктенко, А. З., Любарська, О. М. та ін. (2003). Освітні технології. Київ: IC. A.C.K. (Pekhota, O. M. \& Kiktenko, A. Z, Liubarska, O. M. et al. (2003). Educational technologies. Kyiv: IS. A.S.K). 
Михайлишин, Р. (2016). Метод проектів у початковій школі як педагогічна технологія. Вісник Львівського університету. Серія педагогічна, 30, 43-53 (M ykhailyshyn, R. (2016). The method of projects in primary school as a pedagogical technology. Bulletin of Lviv University. Pedagogical Series, 30, 43-53).

Полат, Е., Петрова, И., Бухаркина, М., Моисеева, М. (2004). Что такое проект? Відкритий урок, 5-6, 10-17 (Polat, E. \& Petrova, I., Bukharkina, M., Moiseeva, M. (2004). What is a project? Open lesson, 5-6,10-17.

Полат, Е. С. (2000). Метод проектов на уроках иностранного языка. Иностранные языки в школе, 3, 3-9 (Polat, E. S. (2000). Method of projects in foreign language lessons. Foreign languages in school, 3, 3-9).

Симоненко, В. Д., Ретивых, М. В., Матяш, Н. В. (1999). Технологическое образование школьников: теоретико-методологчческие аспекты. Брянск: Изд. БГпУ (Simonenko, V. D. \& Retivykh, M. V., Matyash, N. V. (1999). Technological education of schoolchildren: theoretical and methodological aspects. Briansk: Ed. BGPU).

Хуторской, А. В. (2001). Современная дидактика. Санк-Петербург: Питер (Khutorska, A. V. (2001). M odern didactics. Saint Petersburg: Piter).

Новіков, А. М., Новіков, Д. А. (2007). Методологія. М.: Синтег (Novikov, А. М. \& Novikov, D. A. (2007). M ethodology. M.: Sinteg).

Зимняя, И. А., Сахарова, Т. Е. (1991). Проектная методика обучения английскому языку. Иностранные языки в школе, 3, 9-12 (Zimniaia, I. A., Sakharova, T. E. (1991). Project methods of teaching English. Foreign languages in school, 3, 9-12).

Мелашенко, К. М. (2006). Технологія проектного навчання. Завуч, 13 (271), 12-14 (M elashenko, K. M. (2006). Project learning technology. Zavuch, 13 (271), 12-14).

Метод проектів: особливості застосування в початковій школі (2009). Київ: Вид.-во КМПУ ім. Б. Грінченка (Project method: features of application in primary school (2009). Kyiv).

Подобєдова, Т. Ю. (2005). Підготовка майбутніх вчителів гуманітарного профрілю до педагогічного проектування (автореф. дис. канд. пед. наук: 13.00.04). Луганськ (Podobedova, T. Yu. (2005). Preparation of future teachers of the humanities for pedagogical design (PhD thesis abstract). Luhansk).

Енциклопедія освіти (2008). Київ: Юрінком Інтер (Encyclopedia of Education (2008). Kyiv: Yurinkom Inter).

Матяш, Н. В. (2000). Генезис и сущность понятия «Проектная деятельность школьников». Технологическое образование сельских школьников в современных условиях. 146-154 (M atiash, N. V. (2000). Genesis and essence of the concept of "Project activity of schoolchildren". Technological education of rural schoolchildren in modern conditions, 146-154).

Дереклеева, Н. И. (2001). Научно-исследовательская работа в школе. М.: Вербум-М (Derekleeva, N. I. (2001). Research work at school. M .: Verbum-M ).

\section{PEЗЮME}

Прима Раиса, Прима Дмитрий. Проектная деятельность учителя начальной школы: теоретические аспекты.

Целью статьи является раскрытие некоторых аспектов проектной деятельности учителя начальной школы, сущностных признаков метода проектов, проектной технологии. В статье использованы методы исследования: теоретические (анализ справочных изданий, научно-педагогической литературы); интерпретационно-аналитический метод, обобщение. В контексте поиска новых средств и методов формирования творческой личности, ее жизненно важных компетентностей актуализирована проектная деятельность как одна из наиболее 
значимых составляющих образовательного процесса, что создает условия для творческого саморазвития и самореализации учащихся. Проанализированы различные подходы относительно дефиниций «проект», «учебный проект», «метод проектов», «проектная технология», сущностные признаки которых углубляют понимание понятия «проектная деятельность».

Ключевые слова: учитель начальной школы, метод проектов, учебный проект, проект, проектная деятельность, проектная технология, технология обучения.

\section{SUM M ARY}

Prima Raisa, Dmitry Prima. Project activities of primary school teachers: theoretical aspects.

The purpose of this article is to reveal some aspects of the project activity of the primary school teachers, essential features of project method, project technology. The article used research methods: theoretical (analysis of reference books, academic literature); interpretation-analytical method, synthesis. In the context of finding new means and methods of creative personality formation, its vital competencies updated project activity as one of the components of the educational process, which creates conditions for creative selfdevelopment and self-realization of students. There were analyzed different approaches regarding the definitions of "project", "training project", "project method", "project technology", the essential characteristics which enhance the understanding of the concept of "project activities". It is noted that dominant idea that constitutes the semantic core of the concept of "project", is a "pragmatic focus on the result achieved under the solution of this or that practically or theoretically significant problem".

There are selected characteristic features of the method of projects: there is a significant problem for students; first of all - children's interests; the dominance of the principle of independence in students activities; using various forms of school activity: individual, steam room, group; communication theory and practice; communication with real life; maximizing cognitive students' activity; development of creative students' skills, critical thinking skills to search for information; using a variety of methods and means of training; implementation of interdisciplinary connections; integration of knowledge from various branches of science and art; training students which become subjects of the study; including elements of student-centered learning, pedagogy of cooperation, activity-based approach to teaching. There were identified resent attitudes of scientists regarding interpretation of the notion "project method", the lack of a unified and distinct paradigm of its use, that context is understood as a method, technology of teaching, type of training and activities, the availability of scientific texts, alongside the traditional use of the term "project method" in relation to a new concept of "project technology". It defines the essence of project technology and project activities and prospects for the further research.

Key words: primary school teacher, project method, educational project, project activities, project technology, education technology. 